\title{
Performance of Red Chittagong cattle in some selected Areas of Chittagong district of Bangladesh
}

\author{
M Hasanuzzaman', ME Hossain ${ }^{* 1}$, MM I slam ${ }^{1}$, MR Begum ${ }^{2}$, S Chowdhury ${ }^{3}$ and MZ Hossain ${ }^{4}$ \\ ${ }^{1}$ Department of Animal Science and Nutrition; ${ }^{2}$ Department of Basic and Social Sciences; ${ }^{3}$ Department \\ of Medicine and Surgery; ${ }^{4}$ Department of Physiology, Pharmacology and Biochemistry, Chittagong Veterinary \\ and Animal Sciences University, Khulshi, Chittagong 4202, Bangladesh
}

\begin{abstract}
A survey was conducted to estimate the productive and reproductive performances of RCC in Rawjan, Chandanaish, Potia, Satkania and Anowara upazillas of Chittagong, Bangladesh. The farmers of the study areas holding Red Chittagong Cattle (RCC) were divided into large ( $>1.50$ acre), medium (>1.0-1.5 acre), marginal (>0.5-1.0 acre) and landless (>0-0.5 acre) categories. Existing feeding and rearing practices, productive and reproductive performances of RCC were investigated. It was found that, most of the RCCs (82\%) were reared mainly by the marginal farmers. In between May to September, there was a severe shortage of feeds and fodders for RCC. However, despite severe shortage, the farmers were not interested to cultivate fodder. The degree of shortage for feed round the year had significant variation $(p<0.01)$ among the farmers of all categories. Similar to feed shortage, the tendency of growing non-legume crops had marked variation $(P<0.01)$ among the farmers of all categories. Birth weight, weaning weight, daily milk yield, lactation length, calving interval, age at first service, age at first calving and gestation length were $14.5 \mathrm{~kg}, 64.6 \mathrm{~kg}, 2.1$ liters, 216 days, 14 months, 2.7 years, 42 months and 279.9 days respectively. It could therefore be inferred that, productivity of RCC may be increased by improving feeding systems in the study areas.
\end{abstract}

Key words: Red Chittagong Cattle, management, productive and reproductive performance

Bangladesh Animal Husbandry Association. All rights reserved.

Bang. J. Anim. Sci. 2012. 41 (1): 29-34

\section{I ntroduction}

Cattles are important domestic animal in Bangladesh. Most of the indigenous cattles in Bangladesh are of zebu type. Among them, some improved cattles such as, Red Chittagong Cattle (RCC), Pabna cattle, Munsinganj cattle, Manikgonj cattle and North Bengal Grey cattle are potential producers of milk and meat. The RCCs are considered as the national heritage of Bangladesh. They are tropically well adapted and distributed mostly in the southern regions (Raozan, Potia, Anowara and Chandanaish upazillas of Chittagong) of Bangladesh (Hossain 2005). RCC has distinct phenotypic characteristics like smaller size with red coat color, distinct reddish color of muzzle, horn, hoof, ears, eyeball, eyebrow, vulva and tail switch (Mason, 1988). Although milk production of RCC dairy cows are lower than crossbreed cows, their other performances like feed conversion ratio (FCR), production of calf per year and disease resistance capacity are better. They can survive with locally available low quality feed resources (Mondal et al. 2005). Therefore, to improve the productivity of RCC, current study was undertaken addressing the factors associated with production systems of RCC and the dynamics of their feed availability.

\section{Materials and Methods}

\section{Survey area}

The RCCs are concentrated mainly in seven southeastern districts of Bangladesh (Hossain 2005). These areas are located in the boarder Chittagong and Chittagong Hill Tract areas and in boarder of Noakhali areas (Noakhali, Feni, Laksmipur). Therefore, the study area was selected as Rawjan, Chandanaish, Potia, Satkania and Anowara upazillas of Chittagong district on the basis of RCC density.

\section{Data collection}

Data were collected through door to door visit by personal interview from randomly selected individual dairy farmers. A brief introduction regarding the nature and purpose of the study was explained to the farmers before actual interview. Questions were asked systematically and explanation was given wherever necessary. 
Farmers usually did not keep any records of their day to day transactions of farm activities. It was, therefore, difficult to collect actual data and the researcher had to rely on the memory of the farmers. To overcome this problem, of course, all possible efforts were made by the researchers themselves to ensure the collection of reasonably accurate data on recall basis. A pretested questionnaire was prepared on the basis of research methodology and objectives with the help of the livestock officials of the study areas and the data were collected from January 2008 to January 2009.

\section{Data analysis}

Data related with feeding systems, rearing systems, productive and reproductive performances of RCCs were collected from the selected areas and compiled by using Microsoft Excel 2007. Data were subjected to $X^{2}$ test by using Statistical Package for Social Sciences (SPSS 19.5).

\section{Results and discussion}

\section{Categorization of farmer}

The farmers of the research areas were categorized as large ( $>1.50$ acre), medium (>1.0-1.5 acre), marginal (>0.5-1.0 acre) and landless ( $>0-0.5$ acre) class. Marginal size farmers were the highest RCC owner (82\%) (Figure 1), whereas, the landless and medium farmers held $6 \%$ and $9 \%$ RCC, respectively. The large farmers held only $3 \%$ of the RCC.

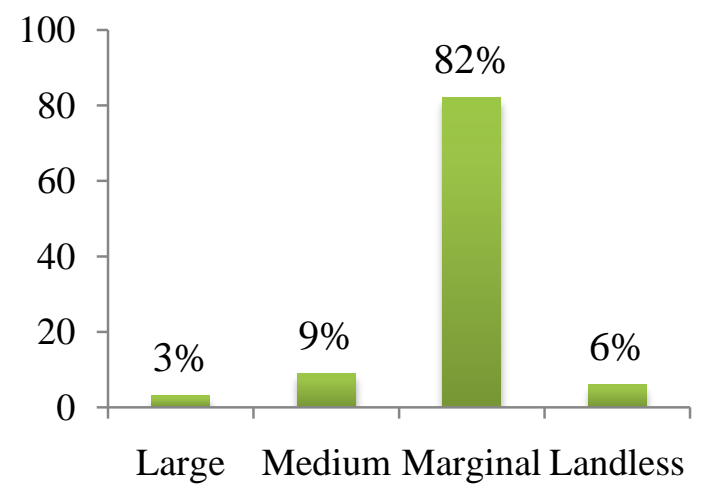

Figure 1. RCC holders according to farm category in the study area

\section{Feeding and management systems}

Stall-feeding was the main system of feeding followed by limited grazing in some cases. They used to supply chopped rice straws (40\%), green forages $(60 \%)$ like road side grass, German (Echinoclora grousgali), Maize (Zea mays), Jumbo (Sorghum vulgare), Sesbania (Sesbania rostarica); concentrate mixture prepared with wheat bran $(20 \%)$, rice polish $(20 \%)$, broken rice $(20 \%)$, oil cake $(20 \%)$, pulse husk $(15 \%)$, soybean meal $(4.5 \%)$ and common salt $(0.5 \%)$ as 'JAU'. The animals were reared in the same style throughout the year.

\section{Feeding of cattle during crisis period}

During shortage of cattle feed, farmers in study areas used tree leaves like jack fruit, banana, acacia etc. to feed their cattle as the main feed resource. The percent of the tree leaves users are shown in Figure 2. It was found that the large category farmers used the highest percentage of tree leaves (34\%) followed by marginal $(30 \%)$, medium $(26 \%)$ and landless (10\%) farmers.

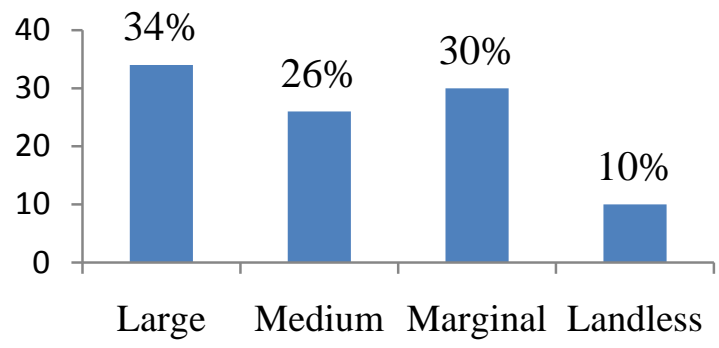

Figure 2. Farmers using tree leaves in the study area

\section{Shortage of feeds and fodders}

It was found that the shortage of feeds and fodders for the farmers of all categories differed significantly $(p<0.05)$ from May to September in comparison to the rest of the months. However, during other months of the year, the shortage was moderate and not remarkable $(P>0.05)$. The drought season might be the reason for the shortage of feed during that time. It was also found that the degree of shortage of feed in each month had significant variation $(P<0.01)$ among the farmers of all categories. It was also found that there was a significant effect $(\mathrm{P}<0.01)$ of season over availability of feed irrespective of the categories of farmers (Table 1 ). 


\section{Rearing of Red Chittagong cattle}

Table 1. Shortage (\% of requirement) of feeds and fodders in different period according to farm category

\begin{tabular}{|c|c|c|c|c|c|c|c|}
\hline \multirow{2}{*}{ Period } & \multicolumn{4}{|c|}{ Type of farmer } & \multirow{2}{*}{ Average } & \multirow{2}{*}{ SE } & \multirow{2}{*}{ Sig. } \\
\hline & Large & Medium & Marginal & Landless & & & \\
\hline January & 17.8 & 20.7 & 27.3 & 32.9 & 24.7 & 3.4 & NS \\
\hline February & 22.3 & 25.9 & 34.1 & 41.1 & 30.9 & 4.2 & NS \\
\hline March & 26.3 & 41.9 & 34.2 & 32.2 & 33.7 & 3.2 & NS \\
\hline April & 60.2 & 80.2 & 70.3 & 52.2 & 65.7 & 6.1 & NS \\
\hline May & 45.8 & 65.1 & 71.0 & 31.3 & 53.3 & 9.1 & $* *$ \\
\hline June & 49.6 & 41.2 & 57.2 & 15.3 & 40.8 & 9.1 & $* *$ \\
\hline July & 44.3 & 32.9 & 56.9 & 55.9 & 47.5 & 5.6 & $*$ \\
\hline August & 60.2 & 37.2 & 40.7 & 25.3 & 40.9 & 7.2 & $* *$ \\
\hline September & 52.8 & 25.6 & 41.1 & 34.9 & 38.6 & 5.7 & $*$ \\
\hline October & 10.2 & 8.9 & 9.1 & 9.9 & 9.5 & 0.3 & NS \\
\hline November & 11.2 & 11.8 & 10.0 & 10.9 & 11.0 & 0.4 & NS \\
\hline December & 15.2 & 15.7 & 10.9 & 11.9 & 13.4 & 1.2 & NS \\
\hline $\mathrm{SE}$ & 5.6 & 6.2 & 6.5 & 4.5 & - & - & - \\
\hline Sig. & $* *$ & $* *$ & $* *$ & $* *$ & - & - & - \\
\hline
\end{tabular}

$\mathrm{SE}$, standard error; NS, non-significant; ${ }^{*}, \mathrm{P}<0.05 ;{ }^{* *}, \mathrm{p}<0.01$

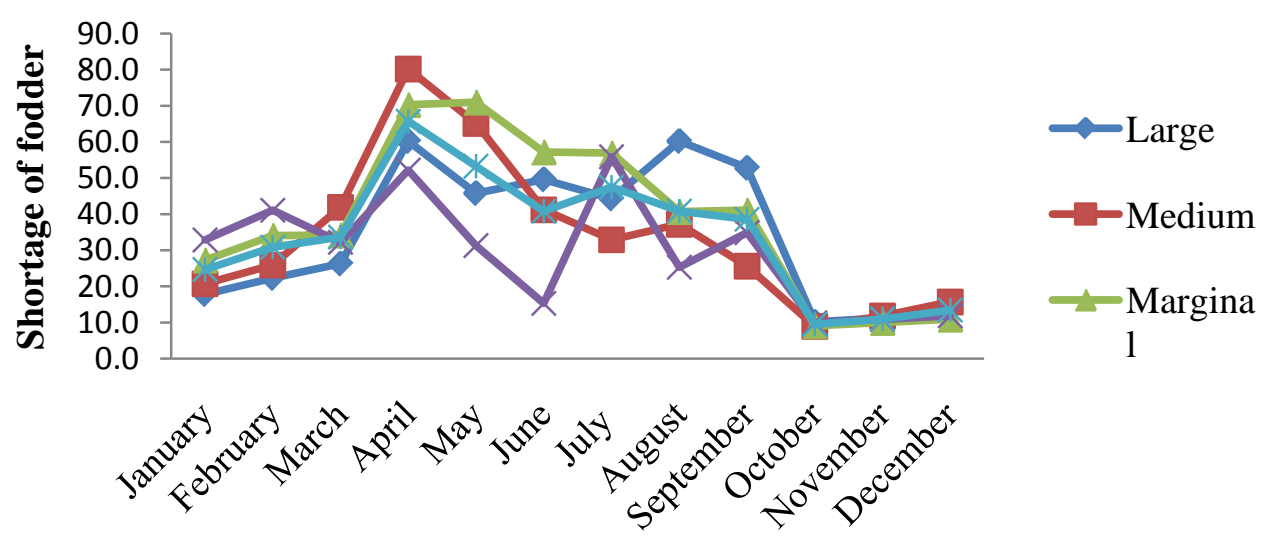

Month of the year

Figure 3. Year round shortage (\% of requirements) of feed according to categories of farmers

It was observed that during April (Figure 3), shortage of feeds were $60.2 \%$ for the large farmers, $80.2 \%$ for the medium farmers, $70.3 \%$ for the marginal farmers and $52.2 \%$ for the landless farmer's. At that period the farmers in the medium category faced highest shortage of feed although the farmers in landless category were with the reverse condition. On the other hand, the farmers of all category faced a little shortage of cattle feed during October to November and the figure was only around $10 \%$. At that period the farmers of all categories might have managed the byproducts of paddy field, hence, feed shortage was minimized.

\section{Cultivation of fodder}

Farmers in the study area usually did not grow fodder crops for their cattle. They had no desire to cultivate fodder at all. However, after long motivation a few number of medium category farmers $(21 \%)$ started to grow fodder like Napier in the high fallow land and German in the water lodging condition (Table 2). It was found that the tendency for growing non- 
legume fodder crops differed significantly $(P>0.01)$ among the farmers of all categories.

Table 2. Types of fodder cultivated according to farm category

\begin{tabular}{lccccc}
\hline \multirow{2}{*}{ Type } & \multicolumn{5}{c}{ Type of farmer } \\
\cline { 2 - 5 } & Large & Medium & Marginal & Landless & \\
\hline A & 15 & 7 & 4 & 2 & $* *$ \\
B & 2 & 1 & 2 & 1 & NS \\
C & 5 & 3 & 1 & 1 & NS \\
D & 78 & 89 & 93 & 96 & NS \\
\hline
\end{tabular}

A, non-legume crop; B, legume crop; C, highyielding grass; $D$, not cultivate; Large $(>1.50$ acre); Medium (>1.0-1.5 acre); Marginal ( $>0.5-$ 1.0 acre); Landless (>0-0.5 acre); NS, nonsignificant; $* *, p<0.01$

\section{Dynamics of feed availability}

It was found that rice straw was available mostly year round. Green road side grasses also were found parallel with it but to a lesser amount. German and some other local grasses were found during rainy season (Table 3 ).

\section{Cultivation of crops/ paddy}

Most of the farmers were cultivating their land three times a year (i.e. Aus, Amon and Boro) and a few of them cultivated two times (i.e. Aus and Amon) due to lack of irrigation facility and prevalence of flood.

Table 3. Dynamics of feed availability in the study areas

\begin{tabular}{ll}
\hline Available Feeds & Availability period \\
\hline Ghata khor, Phul khor, & Mid May to mid \\
Dhan khor, Phuti khor, & October \\
German & \\
$\begin{array}{l}\text { Helencha/Maloncha shak, } \\
\text { rice straw, road side } \\
\text { grasses }\end{array}$ & Year round \\
Napier/HYV grass & Occasionally \\
\hline
\end{tabular}

\section{Productive performance of RCC cows}

\section{Lactation length \& milk yield:}

The daily average milk yield of RCC was 1.9 to 2.3 liters/cow/day (Table 4) which was similar (1.8 to 3.2 liters/cow/day) to the report of Habib et al. (2003), Azizunnessa et al. (2010), Bag et al. (2010) and Habib et al. (2010). Khan et al. (2000) also reported the closer lower values of daily milk yield both in farm $(2.0 \pm 0.63)$ and in rural condition (1.8 \pm 0.9$)$. The average lactation length of RCC cow was 243.1 \pm 25.2 days (Table 4) which was higher than the reports of Bag et al. (2010) as $210.12 \pm 7.59$ days, Azizunnesa et al. (2010) as 238.8 days and Khan et al. (2000) reported as $214.7 \pm 21.8$ days. Mufti et al. (2009) reported the closer values of lactation length of RCC at farm condition (230.6 \pm 23.9 days) whereas Habib et al. (2003) and Habib et al. (2010) also reported a higher lactation length of RCC at

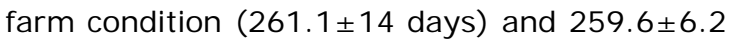
days respectively.

The total milk yield of RCC cows in $1^{\text {st }}, 2^{\text {nd }}, 3^{\text {rd }}$ and $4^{\text {th }}$ lactation were $480.4 \pm 136.8,518.2 \pm$ 78.6, 548.8 \pm 128.3 and $568.0 \pm 189.4 \mathrm{~kg}$, respectively. The highest lactation yield was found in $4^{\text {th }}$ lactation $(568.0 \pm 189.4 \mathrm{~kg})$ and lowest was in $1^{\text {st }}$ lactation $(480.4 \pm 136.8 \mathrm{~kg})$. The average lactation yield of RCC cow was $528.9 \pm 131.9 \mathrm{~kg}$ per lactation. This result is quite close with Habib et al. (2003) who reported the lactation yield of RCC cow as $661.6 \pm 39.8 \mathrm{~kg} /$ lactation. Hossain and Routledge (1982) found lactation yield of local cows as $213.0 \mathrm{~kg}$ under village conditions, which is lower than that of the present study.

\section{Reproductive performance of RCC cows}

\section{Age at First Service}

The average age at first service of RCC was $2.7 \pm 1.7$ years (Table 6 ) which was very much close with the findings of Azizunnesa et al. (2010) as 32.2 months, Bag et al. (20100) as 32.42 months and Ashraf (1998) as 2.6 years for indigenous cattle and was lower than the findings Ali (1994) as 3.5 years and Kamal (2010) as $1216 \pm 121.6$ days.

\section{Gestation length}

The average gestation length of RCC was as $279.9 \pm 5.3$ days, which was similar to the report of Khan et al. (1999), Habib et al. (2003), Habib et al. (2010) and Azizunnesa et al. (2010) as 282, 287, 282 and 280 days, respectively. The findings of the present study were higher than that of Kamal (2010) and Bag et al. (2010) as $283.69 \pm 11.20$ and $283 \pm 7.53$ days, respectively. 


\section{Rearing of Red Chittagong cattle}

Table 4. Lactation length (day), milk yield per day $(\mathrm{kg})$ and total milk yield per lactation $(\mathrm{kg})$ in RCC cows

\begin{tabular}{lccccc}
\hline \multirow{2}{*}{ Characters } & \multicolumn{4}{c}{ Lactation Number } & \multirow{2}{*}{ Average } \\
\cline { 2 - 5 } & $1^{\text {st }}$ & $2^{\text {nd }}$ & $3^{\text {rd }}$ & $4^{\text {th }}$ & \\
\hline Milk yield per day & $1.9 \pm 0.4$ & $2.1 \pm 0.1$ & $2.3 \pm 0.4$ & $2.3 \pm 0.6$ & $2.14 \pm 0.4$ \\
Lactation length & $238.2 \pm 25.4$ & $239.2 \pm 32.4$ & $247.8 \pm 19.9$ & $247.0 \pm 23.0$ & $243.1 \pm 25.2$ \\
Total milk yield & $480.4 \pm 136.8$ & $518.2 \pm 78.6$ & $548.8 \pm 128.3$ & $568.0 \pm 189.4$ & $528.9 \pm 131.9$ \\
\hline
\end{tabular}

\section{Age at first calving}

Average age at first calving of RCC was reported as $42 \pm 1.8$ month which was closer to the findings of Bag et al. (2010), Habib et al. (2010), Ghose et al. (2004) and Mason and Buvanendran (1982).

\section{Calving interval}

The calving interval of RCC cows was $14 \pm 1.2$ month similar to Non-descript Deshi (13-15 months) and lower than crossbred cows (14-16 months). The calving interval of RCC cows was very close to the findings of Habib et al. (2010), Azizunnesa et al. (2010), Kamal (2010), Bag et al. (2010), Alam et al. (1994) and Habib et al. (2003) as 13.6 to 14.50 months.

Table 5. Reproductive performance of RCC in the project area

\begin{tabular}{lcc}
\hline Reproductive traits & Mean & SE \\
\hline Age at first service (years) & 2.7 & 1.7 \\
Gestation length (days) & 279.9 & 5.3 \\
Age at first calving (months) & 42 & 1.8 \\
Calving interval (months) & 14 & 1.2 \\
Birth weight $(\mathrm{kg})$ & 14.5 & 0.8 \\
Weaning weight $(\mathrm{kg})$ & 64.6 & 2.5 \\
\hline
\end{tabular}

\section{Birth Weight}

The average birth weight of the RCC calf was $14.5 \pm 0.8 \mathrm{~kg}$ which was lower than that of 16.67 and $16-17 \mathrm{~kg}$ reported by Habib et al. (2003) and Khan et al. (2000) respectively.

\section{Weaning weight}

The average weaning weight of RCC calf was $64.6 \pm 2.5 \mathrm{~kg}$ that was lower than that of 57.0 $\mathrm{kg}$ reported by Rabeya et al. (2009).

\section{Conclusion}

Most of the RCCs are reared by the marginal category of the farmers. The existing feeding and rearing practices of RCC were very fragile.
The shortage of feeds and fodder for RCC during the period from May to September was severe. At that period they usually offered tree leaves to their cattle. It could therefore be recommended that the persistency of production and length of lactation of RCC may be improved through nutritional management and interventions at the said critical time of year and production cycle.

\section{Acknowledgement}

The authors acknowledge the financial support of Bangladesh Livestock Research Institute, Department of Livestock Services and CVASU for their logistic support.

\section{References}

Alam J, Akteruzzaman M, Rahman A, and Ahmed Z (1994). Comparative performance of local $x$ crossbred cows in Bangladesh. Ind. J. Dairy Sci. 47: 112117.

Ali M (1994). Evaluation of livestock resources and performance of indigenous lactating cows on rice straw-based ration in Bangladesh. A PhD Thesis. Faculty of the Graduate School, University of the Philippines at Los Banos, Philippines.

Ashraf A (1998). A study on some economic traits of indigenous and graded cattle in Khulna region. MS Thesis, Department of Animal Breeding and Genetics, BAU, Mymensingh.

Azizunnesa, Sutradhar BC, Hasanuzzaman M, Miazi OF, Aktaruzzaman M and Faruk MO (2010). Study on the Productive and Reproductive Performances of Red Chittagong Cow at rural areas in Chittagong. Univ. J. Zool. Rajshahi, Univ. 28: 27-31.

Bag MSA, Mannan MA, Khan MSR, Parvez MM and Ullah SM (2010). Morphometric characterization and present status of Red Chittagong cattle (RCC) in 
Chittagong district in Bangladesh. Int. J. BioRes. 1: 11-14.

Ghose SC, Haque M, Rahman M and Saadullah $M$ (2004). A Comparative study of age at first calving, gestation period and calving interval of different breeds of cattle. Bang. Vet. J. 11: 9-14.

Habib MA, Afroz MA and Bhuiyan AKFH (2010). Lactation performance of Red Chittagong Cattle and effects of environmental factors. The Bangladesh Veterinarian, 27: 18-25.

Habib MA, Bhuiyan AKFH and Amin MR (2010). Reproductive performance of Red Chittagong cattle in a nucleus herd. Bang. J. Anim. Sci. 39: 9-19.

Habib MA, Bhuiyan AKFH, Bhuiyan MSA and Khan AA (2003). Performance of Red Chittagong Cattle in Bang. Agril. Univ. Dairy Farm. Bang. J. Anim. Sci. 32: 101108.

Hossain MA and Routledge ST (1982). Performance of crossbred and local cattle under village conditions in Pabna district of Bangladesh. Proceeding of "Maximum Livestock Production from minimum land" Department of Livestock Services. Seminar paper. P. 161-167.

Hossain MM, Bhuiyan MSA, Bhuiyan AKFH and Hanotte O (2005). Red ChittagongIndigenous Cattle Genetic Resource with promise in Bangladesh. Proceedings of the AHAT/BSAS Int. Con., Published by
British Society of Animal Science. 2: 8283.

Kamal MM (2010). A Review on Cattle Reproduction in Bangladesh. Int. J. Dairy Sci. 5: 245-252.

Khan AA, Ali A, Hussain SS and Bhuiyan AKFH (1999). Reproductive Performances of Different Genetic Group of Cows under farm condition. Bang. J. Anim. Sci. 28: 59-64.

Mason IL (1988). A world dictionary of livestock breeds, types and varieties. Third edition, CAB, Wallingford, Oxon, UK.

Mason JL and Buvanendran V (1982). Breeding plans for ruminant livestock in the Tropics. FAO Animal Production and Health paper No. 34-89.

Mondal SC, Alam MM, Rashid MM, Ali MY and Hossain MM (2005) Comparative Study on the productive and reproductive performance of different dairy genotypes reared in Bang. Agril. Univ. dairy farm. Pak. J. Nutr. 4: 222-225.

Mufti, M. M. R., Mostari, M. P., Deb, G. K., Nahar, K. and Huque, K. S. 2009. Genetic diversity of Red Ctittagong Cattle Using Randomly Applied Polymorphic DNA markers. Am. J. Anim. Vet. Sci. 4: 1-5.

Rabeya T, Bhuiyan AKFH, Habib MA and Hossain MS (2009). Phenotypic and genetic parameters for growth traits in Red Chittagong Cattle of Bangladesh. J. Bang. Agril. Univ. 7: 265-271. 